\title{
Effect of Spacing on Seed, Protein, and Oil Production of Four Okra Varieties ${ }^{1}$
}

\author{
Gerardo Mangual-Crespo and Franklin W. Martin ${ }^{2}$ \\ ABSTRACT
}

The yield of okra seed of several varieties was measured as affected by spacing during summer and winter planting. Winter plantings were stunted by short day length but two varieties, Evergreen Velvet and White Velvet, were partially adapted to the winter season. During summer plantings the variety Clemson Spineless outyielded other varieties in seed, oil, and protein yields. A major factor in superior yields was a high seed per pod yield. In addition, this variety yields well at high population densities. The optimum population densities were calculated by quadratic regression. For high-yielding varieties, optimum densities are 6-8 plants per square meter. The protein and oil yields obtained compare favorably with those of other protein and oil producing crops of the tropics.

\section{INTRODUCTION}

Interest in okra as a seed crop yielding protein and oil has been stimulated by Karakoltsides and Constantinides (9), who pointed out the previously unrecognized potential of this vegetable.

Okra appears to be a very desirable crop for the tropics. It is widely adapted and in some areas, such as Brazil, so trouble-free that it is considered a crop that always pays for the effort of planting it. Okra can be produced even during the rainy season, when other grains are very difficult to grow. The seeds of okra are produced in abundance and in some varieties are held in the pod for long periods without shattering. The seeds are easy to harvest, clean, and store, by simple as well as largescale techniques. They can be milled and sifted to provide a useful meal or extracted with water, and protein and oil can be precipitated by simple techniques (11). As a crop for small and for large scale production, okra seed merits study.

Most studies of okra production concern only the harvest of the immature green pod used as a vegetable. Techniques for production of the vegetable are so different from those for the production of seeds that the former studies need no review here. In Louisiana about $2240 \mathrm{~kg}$ / hectare $(2000 \mathrm{lb})$ per acre has been considered a good yield (12).

It is easily observed that during summer months okra plants tend to grow to fit the space allotted to them. Plants with as much as a meter of growing space become very large and bear many pods. As spacing

${ }^{1}$ Manuscript submitted to Editorial Board August 23, 1979.

${ }^{2}$ Assistant Agronomist, Agricultural Experiment Station, University of Puerto Rico, Río Piedras, P. R. and Horticulturist, Mayagüez Institute of Tropical Agriculture, Agricultural Research, Science and Education Administration, USDA, Mayagüez, P. R. 
decreases, the size of plant decreases, as does its fruit production. Therefore, two distinct tendencies can be seen. As plant population density increases, fruit yield increases, but yield per plant decreases. Abregts and Howard (1) found that in okra fields harvested for green fruits, yields increased on a double logarithmic scale for plant population of 16, 32 and 64 plants $/ \mathrm{m}^{2}$. Nevertheless, a limit to yield might be expected at densities where yield per plant decreases with increased plant density at the same rate that yield increases with increased number of plants.

In India, yields of dried seed of the variety Pusa Sawani increased as space between plants decreased from 60 through 45 to $30 \mathrm{~cm}$ (6). Plants could be picked twice for green pods without reducing subsequent seed production. June plantings were more productive than earlier plantings. Apparently optimum densities for maximum seed production were not reached.

The studies reported here were made to find appropriate densities for okra seed production in the hot tropics of Puerto Rico.

\section{MATERIALS AND METHODS}

Seed production was studied in two experiments in Coto clay soil, an acid Oxisol ( $\mathrm{pH}$ about 5.5) in Isabela, Puerto Rico. The first experiment was planted November 27, 1977, an off-season planting date, and consisted of eight commercial varieties: Dwarf Green Long Pod, Clemson Spineless, Red River, Perkin's Spineless, White Velvet, Red Okra, Pusa Sawani, and Evergreen Velvet. Each plot consisted of a single row $3.05 \mathrm{~m}$ long (10 ft.). Plants were established by direct seeding and thinning at $23 \mathrm{~cm}(9$ in) and $30.5 \mathrm{~cm}$ (12 in) intervals. Each variety-distance combination was replicated three times.

Plants were observed for mature height, capsule length, capsule type, capsules per plant, and grams of seed per plant. The yield was extrapolated to estimated yield per hectare.

For the second planting, July 11, 1978, four commercial varieties were used: Evergreen Velvet, Red Okra, White Velvet, and Clemson Spineless. Each plot was $3.7 \mathrm{~m}$ wide wide and $4.6 \mathrm{~m}$ long $(12 \times 15 \mathrm{ft})$. The spacing within plots varied as follows:

\begin{tabular}{ccccc} 
Plot number & $\begin{array}{c}\text { Space briuren rows, } \\
\text { im (in) }\end{array}$ & $\begin{array}{c}\text { Space between plants } \\
\text { in row, cm (in) }\end{array}$ & $M^{2}$ & Areas/plant \\
\hline 1 & $46(18)$ & $23(9)$ & .10 & 1.12 \\
2 & $61(24$ & $23(9)$ & .14 & 1.50 \\
3 & $91.5(36)$ & $23(9)$ & .21 & 2.25 \\
4 & $122(48)$ & $23(9)$ & .28 & 3.00 \\
5 & $46(18)$ & $30.5(12)$ & .14 & 1.50 \\
6 & $61(24)$ & $30.5(12)$ & .19 & 2.00 \\
7 & $91.5(36)$ & $30.5(12)$ & .28 & 3.00 \\
8 & $122(48)$ & $30.5(12)$ & .37 & 4.00 \\
9 & $46(18)$ & $46(18)$ & .21 & 2.25
\end{tabular}




$\begin{array}{ccccc}\text { Plot number } & \begin{array}{c}\text { Space between rows, } \\ \text { cm (in) }\end{array} & \begin{array}{c}\text { Space between plants } \\ \text { in row, cm (in) }\end{array} & M^{2} & \text { Areas/plant } \\ 10 & 61(24) & 46(18) & .28 & 3.00 \\ 11 & 91.5(36) & 46(18) & .42 & 4.50 \\ 12 & 122(48) & 46(18) & .56 & 6.00 \\ 13 & 46(18) & 61(24) & .28 & 3.00 \\ 14 & 61(24) & 61(24) & .37 & 4.00 \\ 15 & 91.5(36) & 61(24) & .56 & 6.00 \\ 16 & 122(48) & 61(24) & .74 & 8.00\end{array}$

The plantings were made as a randomized split block design with four replications. Thus, there were 256 individual plots, each $16.73 \mathrm{~m}^{2}$ (180 $\left.\mathrm{ft}^{2}\right)$.

In spite of these careful preparations, germination was often poor and stands were seldom what was expected. Therefore, the actual numbers of plants surviving to flowering stage were counted and from these counts, actual populations per hectate were calculated.

Plants of the second planting were left in the field until the majority had matured all seed pods (December 7). Plant height was measured three times during the growing season and capsule lengths were measured once. Dry capsules were harvested as necessary and were further dried by exposure to the sun. The seeds were separated from the capsule, and the two fractions were weighed.

The data were subjected to analysis of variance with respect to principal varietal differences. Data were also analyzed by regression of weight of seeds on actual population. This technique permitted graphical comparisons of varieties as well.

The okra plants were grown without irrigation. Actual rainfall and maximum and minimum temperatues follow:

$\begin{array}{lccc} & \begin{array}{c}\text { Rainfall } \\ (\mathrm{mm})\end{array} & \begin{array}{c}\text { Maximum } \\ \text { temperature }(C)\end{array} & \begin{array}{c}\text { Minimum } \\ \text { temperature }(C)\end{array} \\ \text { July } & 126 & 30.0 & 21.1 \\ \text { August } & 236 & 30.6 & 21.6 \\ \text { September } & 182 & 30.0 & 20.6 \\ \text { October } & 130 & 30.0 & 23.9 \\ \text { November } & 56 & 28.9 & 20.6 \\ \text { December } & 8 & 29.4 & 20.6\end{array}$

Samples of seed from the plots were tested for protein by AOAC methods (7) and for oil by techniques of the American Oil Chemists' Society (2).

\section{RESULTS}

The first planting of okra, made near the beginning of the season of short day lengths (winter), was stunted normally due to the short-day response of all varieties. Nevertheless, varietal differences were apparent. Table 1 gives the characteristics of the plants, the yields, and the 
estimated yields per hectare of seeds. Particularly impressive were the varieties Evergreen Velvet and White Velvet. These varieties are slow to develop, but plants become larger and are heavy bearers. They can be considered possible winter varieties for Puerto Rico. The capsules of Evergreen Velvet were the largest, but those of White Velvet were the smallest. Seed yields were about equal for the two cultivars, but they responded differently to the two spacings (table 1). Total yields were very good considering that the planting was off-season. The standard variety Clemson Spineless did not yield well during the winter season. The horn or nondehiscent capsule type found in the two velvet varieties was observed to be superior for seed production purposes, for it holds the seed

TABLE 1.-Seed yields and other characteristics of eight okra seed varieties in offseason (winter) plantings

\begin{tabular}{|c|c|c|c|c|c|c|}
\hline Variety & Spacing & $\begin{array}{l}\text { Plant } \\
\text { height }\end{array}$ & $\begin{array}{l}\text { Capsule } \\
\text { length }\end{array}$ & $\begin{array}{c}\text { Capsule } \\
\text { type }^{1}\end{array}$ & $\begin{array}{l}\text { Actual } \\
\text { yield }\end{array}$ & $\begin{array}{l}\text { Extrapolated } \\
\text { Yield }\end{array}$ \\
\hline & $\mathrm{Cm}$ & $M$ & $\mathrm{Cm}$ & & $G / p l a n t$ & $\mathrm{Kg} /$ hectare \\
\hline \multirow[t]{2}{*}{ Evergreen Velvet } & 23 & .80 & 18 & ND & 578 & 830 \\
\hline & 30.5 & .67 & 18 & ND & 719 & 1032 \\
\hline \multirow[t]{2}{*}{ Pusa Sawani } & 23 & .48 & 15 & D & 428 & 614 \\
\hline & 30.5 & .69 & 15 & $\mathrm{D}$ & 294 & 422 \\
\hline \multirow[t]{2}{*}{ Red Okra } & 23 & .73 & 18 & ND & 347 & 498 \\
\hline & 30.5 & .87 & 16.5 & ND & 280 & 402 \\
\hline \multirow{2}{*}{ White Velvet } & 23 & 1.04 & 11 & ND & 837 & 1201 \\
\hline & 30,5 & 1.10 & 13 & ND & 524 & 752 \\
\hline \multirow[t]{2}{*}{ Red River } & 23 & .86 & 13 & ND & 319 & 457 \\
\hline & 30.5 & .82 & 13 & ND & 279 & 400 \\
\hline \multirow[t]{2}{*}{ Clemson Spineless } & 23 & .78 & 15 & $\mathrm{D}$ & 465 & 667 \\
\hline & 30.5 & .70 & 15 & $\mathrm{D}$ & 310 & 445 \\
\hline \multirow[t]{2}{*}{ Dwarf Green Long } & 23 & .56 & 14 & $\mathrm{D}$ & 492 & 706 \\
\hline & 30.5 & .60 & 14 & $\mathrm{D}$ & 406 & 583 \\
\hline \multirow[t]{2}{*}{ Perkin's Spineless } & 23 & .79 & 13 & ND & 512 & 735 \\
\hline & 30.5 & .57 & 11 & ND & 298 & 428 \\
\hline
\end{tabular}

${ }^{\prime} \mathrm{D}=$ dehiscent; $\mathrm{ND}=$ not readily dehiscing.

on the plant for a long period of time and shelters the seed from frequent wetting in light showers.

Most plants reached only about $1 \mathrm{~m}$ of height, 40 to $60 \%$ of the height expected in summer planting. Capsules were somewhat shorter than those from comparable summer plantings (see table 2 for comparable data).

For all cases except Evergreen Velvet, seed yield was reduced at the $30.5 \mathrm{~cm}$ spacing as compared to the $23 \mathrm{~cm}$ spacing. Average seed yield at $30.5 \mathrm{~cm}$ spacing was $558 \mathrm{~kg} /$ hectare, compared to $713 \mathrm{~kg} /$ hectare for the $23 \mathrm{~cm}$ spacing. Thus, increasing population density by $33 \%$ increased seed yield by $28 \%$. Optimum spacing for maximum seed yields for winter plantings is probably less than $23 \mathrm{~cm}$ between plants. 
Tables 2 and 3 show differences in cultivars observed in the summer planting. Table 3 shows those characteristics that were subject to analysis of variance. Significant differences were found in each characteristic. The highest seed yield per plot was in the variety Clemson Spineless, yet this variety had neither more plants per plot nor capsules per plot. The lowest seed yield per plot was in White Velvet, the variety with the largest population, yet with the fewest capsules per plot. The amount of seed in all varieties represented $52-54 \%$ of the weight of the capsules (seed and chaff).

Table 2 gives characteristics of individual plants. Plants were much taller and capsules were slightly longer in the summer than in the winter

TABLE 2.-Differences in plant characteristics of four okra varieties during the summer planting

\begin{tabular}{lcccccc}
\hline \multicolumn{1}{c}{ Variety } & $\begin{array}{c}\text { Mature } \\
\text { height }\end{array}$ & $\begin{array}{c}\text { Capsule } \\
\text { length }\end{array}$ & $\begin{array}{c}\text { Capsules/ } \\
\text { plant }\end{array}$ & $\begin{array}{c}\text { Weight of } \\
\text { seeds/ } \\
\text { plant }\end{array}$ & $\begin{array}{c}\text { Weight of } \\
\text { chaff/ } \\
\text { plant }\end{array}$ & $\begin{array}{c}\text { Weight of } \\
\text { seeds/ } \\
\text { capsule }\end{array}$ \\
\hline EvergreenVelvet & $\mathrm{Cm}$ & $\mathrm{Cm}$ & & $g$ & $g$ & $\mathrm{~g}$ \\
Red Okra & 288 & 22.1 & 21.4 & 85 & 79 & 3.99 \\
Clemson Spineless & 151 & 22.8 & 12.1 & 59 & 53 & 4.88 \\
White Velvet & 147 & 19.2 & 14.7 & 85 & 77 & 5.79 \\
\hline
\end{tabular}

TABLE 3.-Differences on a plot basis of selected characteristics of four okra varieties in the summer planting

\begin{tabular}{lcccc}
\hline \multicolumn{1}{c}{ Variety } & $\begin{array}{c}\text { Plants per } \\
\text { plot }\end{array}$ & $\begin{array}{c}\text { Capsules per } \\
\text { plot }\end{array}$ & $\begin{array}{c}\text { Weight of } \\
\text { seed }\end{array}$ & $\begin{array}{c}\text { Weight of } \\
\text { chaff }\end{array}$ \\
\hline & & & $K g / p l o t$ & $K g / p l o t$ \\
Evergreen Velvet & $36.47 \mathrm{~b}^{\prime}$ & $780 \mathrm{a}$ & $3.11 \mathrm{~b}$ & $2.88 \mathrm{~b}$ \\
Red Okra & $52.77 \mathrm{a}$ & $639 \mathrm{ab}$ & $3.12 \mathrm{~b}$ & $2.82 \mathrm{~b}$ \\
Clemson Spineless & $49.86 \mathrm{a}$ & $732 \mathrm{ab}$ & $4.24 \mathrm{a}$ & $3.83 \mathrm{a}$ \\
White Velvet & $57.35 \mathrm{a}$ & $603 \mathrm{c}$ & $2.44 \mathrm{c}$ & $2.07 \mathrm{c}$ \\
\hline
\end{tabular}

'Means followed by the same letter(s) do not differ significantly at $(\mathrm{P}=.05)$.

planting. Seed yields per plant were much higher in Clemson Spineless and Evergreen Velvet than in the other two varieties. Clemson Spineless had relatively few capsules with a high seed weight, while Evergreen Velvet had many capsules, but with fewer seeds per capsule. Seeds per capsule does not appear to be closely related to the length of the capsule. These data help explain Clemson Spineless high plot yields, which are clearly related to high seed yields per capsule.

Table 4 gives the seed yields of the four cultivars, extrapolated from plot yields to ton/hectare. Although population size varied by a factor of 11, seed yields varied by a factor of about 3 . This can be explained from the observation that plants are larger and produce more capsules when 
populations are low. Thus, as populations increase in size, plants are stunted, but up to a point yields may still increase.

The relationship between population size and seed yield can thus best be studied by regression. Because varieties differ in response to population size, this regression is best calculated separately for each variety. Furthermore, because two opposing tendencies influencing seed production occur, i.e., increase of total seed yield with increased plant density, and decrease of seed yield per plant with increased plant density, the relationship between seed production and density would not be expected to be linear over all population densities.

Regression analysis showed that yields of seed are related to plant densities by a quadratic relationship. Table 5 gives the regression equations best relating yield to plant density. The statistical probability of

TABLE 4.-Range of seed yields (tons/hectare) of four okra varieties during the summer planting

\begin{tabular}{lrccc}
\hline \multicolumn{1}{c}{ Variety } & \multicolumn{3}{c}{ Seed yield } & $\begin{array}{c}\text { Calculated } \\
\text { for optimum } \\
\text { population }\end{array}$ \\
\cline { 2 - 4 } & Low & Mean & High & 2.30 \\
Evergreen Velvet & 0.64 & 1.84 & 3.26 & 2.26 \\
Red Okra & .98 & 1.87 & 2.92 & 3.33 \\
Clemson Spineless & 1.18 & 2.54 & 4.00 & 1.88 \\
White Velvet & .54 & 1.46 & 2.45 & \\
\hline
\end{tabular}

TABLE 5.-Quadratic regression of seed weight on number of plants per plot

\begin{tabular}{lccc}
\hline \multicolumn{1}{c}{ Variety } & \multicolumn{1}{c}{ Regression equation } & P & $\mathrm{r}$ \\
\hline Evergreen Velvet & $\mathrm{WS}=1.0337+0.0877(\mathrm{PPP})-0.000658(\mathrm{PPP})^{2}$ & .0121 & .63 \\
Red Okra & $\mathrm{WS}=1.6371+0.0408(\mathrm{PPP})-0.000194(\mathrm{PPP})^{2}$ & .0956 & .60 \\
Clemson Spineless & $\mathrm{WS}=2.3832+0.0501(\mathrm{PPP})-0.000196(\mathrm{PPP})^{2}$ & .0246 & .64 \\
White Velvet & $\mathrm{WS}=0.3985+0.0575(\mathrm{PPP})-0.000300(\mathrm{PPP})^{2}$ & .008 & .60 \\
\hline
\end{tabular}

this relationship is given in the probability column, and because it is less than .05 in all cases but that of the cultivar Red Okra, it signifies that the data fit this hypothesis. The correlation coefficients of actual data with the theoretical curves are given in the final column. These correlations are fairly high. It is supposed that yields are also influenced by other factors such as microclimate, soil fertility, drainage, etc., so higher correlations are not expected.

Figure 1 shows curves of the seed yields that can be expected for the four varieties. Three of the four curves are similar in shape although they differ in height. That of Evergreen Velvet is completely different and may reflect a basic physiological difference. The curves all reach a broad maximum that suggests that seed yields will be about the same for populations that differ considerably. For example, the curve suggests that 


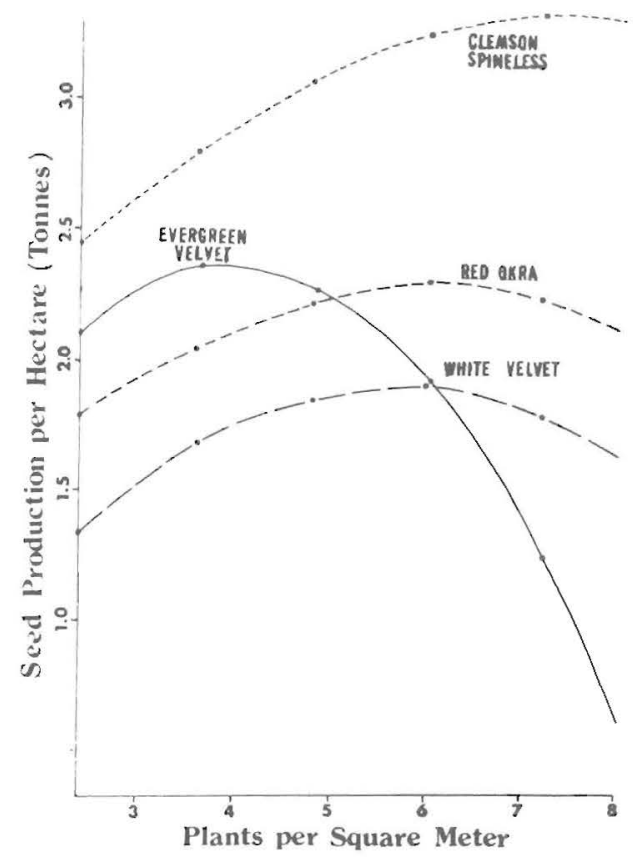

FIG. 1.-Seed yield of four okra varieties planted at the Isabela Substation July, 1978.

TABLE 6.-Populations and spacings expected to maximize seed yields of four varieties of okra

\begin{tabular}{|c|c|c|c|}
\hline \multirow{2}{*}{ Variety } & \multirow{2}{*}{$\begin{array}{l}\text { Approximate optimum } \\
\text { population per hectare }\end{array}$} & \multicolumn{2}{|c|}{ Suggested spacing $(\mathrm{cm})$} \\
\hline & & Optimum & Practical \\
\hline Evergreen Velvet & 36,000 & $53 \times 53$ & $28 \times 100$ \\
\hline Red Okra & 60,000 & $41 \times 41$ & $17 \times 100$ \\
\hline Clemson Spineless & 72,000 & $37 \times 37$ & $14 \times 100$ \\
\hline White Velvet & 60,000 & $41 \times 41$ & $17 \times 100$ \\
\hline
\end{tabular}

maximum seed yields can be obtained in the case of Clemson Spineless with 6 to 8.6 plants per meter (58,000-86,000 plants/hectare).

Table 6 gives the optimum populations per hectare, as calculated from regression analysis, and also appropriate spacings. Clemson Spineless, the highest yielding variety, is the variety that can tolerate the closest spacing. Yields predicted on the basis of optimum population are compared to lowest, mean, and high yields in table 4. Highest yields actually obtained were higher than those predicted from the regression analysis because such analysis is based on average, not on extremes.

Table 7 shows the contents of oil and protein measured in seeds of the 
four varieties. These represent measurements of the seed actually harvested from the plots. No attempt has been made to evaluate the effect of plant density on the oil and protein content of the seed itself.

The actual percentage of oil and protein were extrapolated to production per hectare at the optimum populations, as calculated from the

TABLE 7.-Content oil and protein yields ( $\mathrm{kg} / \mathrm{hectare}$ ) of four okra varieties based on calculated yields for optimum population, and on highest plot yields

\begin{tabular}{lcccccccc}
\hline \multirow{2}{*}{ Variety } & \multicolumn{2}{c}{$\begin{array}{c}\text { Measured content } \\
\text { percent }\end{array}$} & & \multicolumn{2}{c}{ Protein } & & \multicolumn{2}{c}{ Oil } \\
\cline { 2 - 3 } & Protein & Oil & & $\begin{array}{c}\text { Optimum } \\
\text { Population }\end{array}$ & Best plot & $\begin{array}{c}\text { Optimum } \\
\text { population }\end{array}$ & Best plot \\
\hline Evergreen Velvet & 18.43 & 20.5 & & 423.9 & 600.8 & & 471.5 & 668.3 \\
Red Okra & 19.37 & 24.3 & & 437.8 & 565.6 & & 549.2 & 709.6 \\
Clemson Spineless & 19.72 & 24.1 & & 657.7 & 788.8 & & 802.5 & 964.0 \\
White Velvet & 20.98 & 19.8 & & 394.4 & 514.0 & & 372.2 & 485.1 \\
\hline
\end{tabular}

TABLE 8.-Protein production in $\mathrm{kg} /$ hectare of some important crop plants, as compared to okra

\begin{tabular}{|c|c|c|c|}
\hline Crop group & Species or variety & $\begin{array}{l}\mathrm{Kg} / \mathrm{ha} \\
\text { protein }\end{array}$ & Source \\
\hline \multirow[t]{4}{*}{ Okra } & Clemson Spineless & 658 & These experiments \\
\hline & White Velvet & 394 & These experiments \\
\hline & Evergreen Velvet & 424 & These experiments \\
\hline & Red Okra & 438 & These experiments \\
\hline \multirow[t]{5}{*}{ Cereals } & Maize & 504 & Kaul (9) \\
\hline & Wheat & 752 & Kaul (9) \\
\hline & Buckwheat & 480 & Dendy et al. (5) \\
\hline & Quinoa & 160 & Dendy et al. (5) \\
\hline & Teosinte & 168 & Dendy et al. (5) \\
\hline \multirow[t]{6}{*}{ Pulses or legumes } & Mung bean & 200 & Kaul (9) \\
\hline & Red gram & 348 & Jeswani (8) \\
\hline & Urd bean & 338 & Jeswani (8) \\
\hline & Bambarra groundnut & 160 & Dendy et al. (5) \\
\hline & Cowpea & 330 & Dendy et al. (5) \\
\hline & Lupin & 350 & Dendy et al. (5) \\
\hline \multirow[t]{5}{*}{ Oil seeds } & Safflower & 435 & Betschart et al. (3) \\
\hline & Sunflower & 195 & Betschart et al. (3) \\
\hline & Soybean & 750 & Circle and Smith (4) \\
\hline & Sesame & 180 & Betschart (3) \\
\hline & Castor & 175 & Betschart et al. (3) \\
\hline \multirow[t]{6}{*}{ Vegetables } & Potato & 412 & Kaul (10) \\
\hline & Pumpkin seed & 235 & Dendy et al. (5) \\
\hline & Melon seed & 70 & Dendy et al. (5) \\
\hline & Green kale & 600 & Shepherd (14) \\
\hline & Edible pod mung bean & 632 & Munger $^{3}$ \\
\hline & Cabbage & 444 & Munger $^{3}$ \\
\hline
\end{tabular}

\footnotetext{
${ }^{3}$ Munger, H., 1979. Personal communication.
} 
regression equations, and the highest producing plot observed. Values per best plot were always higher than values calculated for optimum populations. Clemson Spineless was again the most productive variety.

Yields of protein expected from optimum populations of okra are compared with yields reported from various other crops (table 8). This comparison shows that okra seed can yield as much protein per hectare as almost all important protein crops of the world. Its protein production per hectare is definitely excelled only by that of wheat and soybean.

Table 9 compares the average oil production of okra varieties in this experiment to that of other oil-producing crops. The African oil palm is recognized to be a superior source of oil, far outranking all other sources. However, okra seed appears to be an excellent oil source, capable of yielding at least as much oil as other important oil crops of the temperate zone and the tropics.

TABLE 9.-Average oil production in $\mathrm{kg} /$ hectare of some important crop plants as compared to okra (means per experiment)

\begin{tabular}{lcl}
\hline \multicolumn{1}{c}{ Species or variety } & $\mathrm{Kg} / \mathrm{ha}$ oil & \multicolumn{1}{c}{ Source } \\
\hline Okra & & \\
$\quad$ Clemson Spineless & 612 & These experiments \\
White Velvet & 289 & These experiments \\
Evergreen Velvet & 377 & These experiments \\
Red Okra & 454 & These experiments \\
Coconut & 600 & Ochse et al. (13) \\
Oil palm & 2200 & Ochse et al. (13) \\
Soybean & 300 & Betschart et al. (3) \\
Sunflower & 450 & Betschart et al. (3) \\
Safflower & 600 & Betschart et al. (3) \\
Sesame & 360 & Betschart et al. (3) \\
Peanut & 360 & Ochse et al. (13) \\
Flaxseed & 225 & Betschart et al. (3) \\
Castor & 485 & Betschart et al. (3) \\
\hline
\end{tabular}

\section{DISCUSSION}

In this first experiment to determine effects of spacing on seed, protein, and oil production of okra in Puerto Rico, it has been clearly shown that the average production of protein and oil is comparable or superior to protein and oil production of traditional crops of the temperate zone and the tropics. It must be concluded that okra seed is a potentially important protein and oil crop for the tropics.

The comparison of varieties showed that some are much more productive than others. Furthermore, varieties vary in response to different population densities. The yield of the most productive varieties is highest at population densities of six or more plants $/ \mathrm{m}^{2}$. In the testing of existing varieties or the development of new varieties, close spacing should be the 
rule in order that potentially productive varieties have the opportunity to demonstrate their usefulness.

\section{RESUMEN}

El rendimiento de semilla de quimbombó se midió con respecto a la influencia del espaciamiento entre plantas en siembras de verano e invierno. El crecimiento de las siembras en invierno se retardó en los días cortos, pero dos variedades se destacaron como aptas para esa estación: Evergreen Velvet y White Velvet. En verano la variedad Clemson Spineless rindió mejor que otras en términos de semilla, aceite y proteína. Un factor importante asociado con sus altos rendimientos fue sus numerosas semillas por vaina. Esta variedad rinde bien cuando la siembra es bien densa. Las densidades de siembra óptimas se calcularon a base de regresión cuadrática. De 6 a 8 plantas por $\mathrm{m}^{2}$ es la mejor densidad para las variedades de altos rendimientos. Los rendimientos de proteína y aceite comparan muy favorablemente con los de otros cultivos de trópico.

\section{LITERATURE CITED}

1. Abregts, E. E. and Howard, C. M., 1974. Response of okra to plant density and fertilization, HortScience 9 (4): 400 .

2. American Oil Chemists' Society, 1975. Sampling and analysis of oil seed by-products, $\mathrm{Ba} 7-58,5 \mathrm{pp}$. In: Official and Tentative Methods of the American Oil Chemists' Society, Champaign, Illinois.

3. Betschart, A., Lyon, C. K. and Kohler, G. O., 1975. Sunflower, Safflower, Sesame, and Castor Protein. In: Pirie, N. W. (Ed). Food Protein Sources, Cambridge University Press, London, pp. 1-8.

4. Circle, S. J. and Smith, A. K., 1975. Soybeans: Processing and Products. In: Pirie, N. W. (Ed). Food Protein Sources, Cambridge University Press, London, pp. 47-64.

5. Dendy, D. A. V., Emmett, B. and Oke, O. L., 1975. Minor Food Seeds. In: Pirie, N. W. (Ed). Food Protein Sources, Cambridge University Press, London, pp. 19-26.

6. Grewal, B. S., Nandpuri, K. S. and Kumar, J. C., 1972. Effect of date of sowing, spacing, and picking of green pods on seed production of okra, Punjab Hort. J. 12:248-54.

7. Horwitz, W. (Ed), 1965. Official Methods of Analysis of the Association of Official Agricultural Chemists, Assoc. Off. Agri. Chem. Washington, D. C., pp. 744-745.

8. Jeswani, L. M., 1975. Varietal Improvement of Seed Legumes in India. In: Pirie, N. W. (Ed). Food Protein Sources, Cambridge University Press, London, pp. 9-18.

9. Karakoltsides, P. A. and Constantinides, S. M., 1975. Okra seeds: a new protein source, J. Agri. Food Chem. 23 (6):1204-07.

10. Kaul, A. K., 1975. Protein Rich Cereal Grains. In: Pirie, N. W. (Ed). Food Protein Sources, Cambridge University Press, London, pp. 1-8.

11. Martin, F. W. and Ruberté, R., 1979. Milling and use of okra seed meal at the household level. J. Agri. Univ. P. R. 63 (1):1-7.

12. Miller, J. C., 1949. Growing okra seed for its oil, Chemurg. Dig. May 22.

13. Ochse, J. J., Soule, M. J., Jr., Dijkman, M. S. and Wehlburg, C., 1961. Tropical and Subtropical Agriculture. Macmillan Co., New York.

14. Shepherd, F. W., 1975. Vegetables. In: Pirie, N. W. (Ed). Food Protein Sources, Cambridge University Press, London, pp. 27-32. 